\title{
Physico-Chemical Properties and Available N, P, K and S in Soils of Harahua Block of Varanasi district, Uttar Pradesh
}

\author{
Vibha Singh, R.P. Singh*, S.K.S. Chandel and S. K. Patel \\ Department of Agricultural Chemistry and Soil Science, Udai Pratap (Autonomous) College, Varanasi-221002, \\ Uttar Pradesh, India
}

Soil is an important resource for production system but its productivity is declining day by day due to increasing degradation. The excessive use of fertilizers including agro-chemicals and water under monotonous cropping system to increase the food production, particularly in Indo-Gangetic Plain, resulted in detrimental effect on soil ecosystem (Jagdish Prasad 2004). To maintain the equilibrium in productivity vis-àvis soil environment, it is necessary to periodically monitor the soil properties and nutrient availability. Soil testing provides information about nutrients availability in soil which forms the basis for the fertilizer recommendation for sustainable production (Doneriya et al. 2013). Present study was conducted to analyze the physico-chemical properties and nutrients in soils of an agriculturally important Harahua block of Varanasi district, Uttar Pradesh. Seventy five soils samples (0-15) were collected from Bhelkha (V1), Chamaon (V2), Koiran (V3), Bhawanipur (V4), Pissaur (V5), Daniyalpur (V6) and Ganeshpur (V7) villages of Harhua block of Varanasi district. Sorghum, pearl millet, maize, paddy, pigeon pea and green gram are major crops during kharif, while wheat, mustard, field pea, and potato are commonly grown in rabi season. Quartering technique was used for preparation of soil sample. The samples were air-dried and passed through $2 \mathrm{~mm}$ sieve for analysis. The soil $\mathrm{pH}$ and $\mathrm{EC}$ were determined with 1:2.5 soil water ratio. The soil samples were analyzed for sand silt and clay (Chopra and Kanwar 1999); organic carbon (Walkley and Black 1934); available N

*Corresponding author: (Email: drraghvendraupc@gmail.com)
(Subbiah and Asija1956); available P (Olsen 1954); available K (Jackson 1973); available S (Hariram and Dwivedi 1994), bulk density, particle density and porosity following standard procedures. Porosity and nutrient index value (Ghosh and Hasan 1976, 1979 and 1980) were calculated by using the formulae.

$$
\text { Porosity }=\left(100-\frac{\mathrm{BD}}{\mathrm{PD}}\right) \times 100
$$

Nutrient Index Value $=$

[ $(\%$ soils high in available estimates of a nutrient $\times 3)+(\%$ soils medium in available quantities $\times 2)+(\%$ soils low in available quantities $\times 1)] \div 100$

The soil $\mathrm{pH}$ varied from 6.1 to 8.5 (Table 1 ). About $57 \%$ samples were neutral (pH 6.6 to 7.3), $29 \%$ samples were mildly alkaline (pH 7.4 to 7.8$)$ and $13 \%$ samples were moderately alkaline (pH 7.9 to 8.4). The electrical conductivity of the soils varied from $0.22-0.47$ $\mathrm{dS} \mathrm{m} \mathrm{m}^{-1}$ and were found to be normal $\left(\mathrm{EC}<1.0 \mathrm{dS} \mathrm{m}^{-1}\right)$. The sand, silt and clay content of the soils varied from $31.1-52.1 \%, 18-30 \%$ and $18-35.2 \%$ with mean values of 43.8, 23.6 and 26.1, respectively, with standard deviations of $6.35,4.53$ and 5.58. Bulk density and particle density ranged from 1.21-1.47 $\mathrm{Mg} \mathrm{m}^{-3}$ and 2.00 to $2.77 \mathrm{Mg} \mathrm{m}^{-3}$. The porosity of the soils ranged from 27 - $57 \%$ with mean value of $46.8 \%$ and standard deviation of 5.88. According to Muhr et al. (1965) rating, the organic carbon content ranged from 0.30 to $0.75 \%$ with an average of $0.63 \%$ and standard deviation of 0.09 . About $9 \%$ samples had organic carbon content below $0.50 \%$ and $90 \%$ samples were between 0.50 $0.75 \%$. 
Table 1. Physico-chemical properties of soils of Harahua block

\begin{tabular}{|c|c|c|c|c|c|c|c|c|c|c|}
\hline Site & $\begin{array}{c}\text { No. of } \\
\text { samples }\end{array}$ & $\begin{array}{c}\text { Sand } \\
(\%)\end{array}$ & $\begin{array}{l}\text { Silt } \\
(\%)\end{array}$ & $\begin{array}{l}\text { Clay } \\
(\%)\end{array}$ & $\begin{array}{c}\text { BD } \\
\mathrm{g} \mathrm{cm}^{-3}\end{array}$ & $\begin{array}{c}\text { PD } \\
\mathrm{g} \mathrm{cm}^{-3}\end{array}$ & $\begin{array}{c}\text { Porosity } \\
(\%)\end{array}$ & pH & $\begin{array}{c}\text { EC } \\
\text { dS } \mathbf{m}^{-1}\end{array}$ & $\begin{array}{l}\text { OC } \\
(\%)\end{array}$ \\
\hline $\mathrm{V}_{1}$ & 11 & 47.3 & 25.1 & 24.7 & 1.29 & 2.41 & 48.0 & 7.3 & 0.31 & 0.66 \\
\hline $\mathrm{V}_{2}$ & 10 & 44.4 & 23.3 & 29.7 & 1.25 & 2.46 & 48.2 & 7.2 & 0.36 & 0.56 \\
\hline $\mathrm{V}_{3}$ & 12 & 40.7 & 23.7 & 25.6 & 1.39 & 2.42 & 44.2 & 7.1 & 0.35 & 0.62 \\
\hline $\mathrm{V}_{4}$ & 11 & 41.3 & 23.7 & 25.2 & 1.30 & 2.39 & 47.4 & 7.0 & 0.39 & 0.61 \\
\hline $\mathrm{V}_{5}$ & 10 & 43.1 & 24.1 & 27.9 & 1.34 & 2.31 & 42.6 & 7.3 & 0.37 & 0.63 \\
\hline $\mathrm{V}_{6}$ & 10 & 45 & 22.5 & 22.6 & 1.36 & 2.29 & 48.1 & 7.0 & 0.36 & 0.69 \\
\hline \multirow[t]{3}{*}{$\mathrm{V}_{7}$} & 11 & 44.7 & 23.1 & 27.8 & 1.30 & 2.56 & 49.1 & 7.7 & 0.37 & 0.65 \\
\hline & Mean & 43.8 & 23.6 & 26.1 & 1.31 & 2.40 & 46.8 & 7.2 & 0.35 & 0.63 \\
\hline & S.D. & 6.35 & 4.53 & 5.58 & 0.067 & 0.20 & 5.88 & 0.53 & 0.056 & 0.09 \\
\hline
\end{tabular}

* From all the samples analysed

Available N content varied from 136 to $300 \mathrm{~kg}$ $\mathrm{ha}^{-1}$ and available $\mathrm{P}$ from 11 to $28.5 \mathrm{~kg} \mathrm{ha}^{-1}$ (Table 2). The available $\mathrm{K}$ in the soils ranged from 121 to $369 \mathrm{~kg} \mathrm{ha}^{-1}$. For N, $86 \%$ of soil samples were found to be in low category ( $\leq 280 \mathrm{~N} \mathrm{~kg} \mathrm{ha}^{-1}$ ). In case of phosphorus, $90 \%$ of soil samples were under medium (11-25 $\left.\mathrm{P}_{2} \mathrm{O}_{5} \mathrm{~kg} \mathrm{ha}^{-1}\right)$ category and remaining in the high $\left(>25 \mathrm{P}_{2} \mathrm{O}_{5} \mathrm{~kg} \mathrm{ha}^{-1}\right)$ category. About $66.6 \%$ of samples were in the medium $\left(121-280 \mathrm{~kg} \mathrm{ha}^{-1}\right)$ range for available $\mathrm{K}$ and remaining samples were in high $\left(>280 \mathrm{~K}_{2} \mathrm{O} \mathrm{kg} \mathrm{ha}{ }^{-1}\right)$ category. The available sulphur varied from $6-19 \mathrm{mg} \mathrm{kg}^{-1}$ and $29 \%$ samples were found to be deficient $\left(<10 \mathrm{mg} \mathrm{kg}^{-1}\right)$ and remaining $70 \%$ samples were under medium $(10-20$ $\mathrm{mg} \mathrm{kg}^{-1}$ ) category (Hariram and Dwivedi 1994).

Table 2. N, P, K and S status of soils of Harahua Block

\begin{tabular}{cccccc}
\hline Site & No. of samples & $\begin{array}{c}\text { Nitrogen } \\
\left(\mathrm{kg} \mathrm{ha}^{-1}\right)\end{array}$ & $\begin{array}{c}\text { Phosphorus } \\
\left(\mathrm{kg} \mathrm{ha}^{-1}\right)\end{array}$ & $\begin{array}{c}\text { Potassium } \\
\left(\mathrm{kg} \mathrm{ha}^{-1}\right)\end{array}$ & $\begin{array}{c}\text { Sulphur } \\
(\mathrm{ppm})\end{array}$ \\
\hline $\mathrm{V}_{1}$ & 11 & 210.9 & 15.5 & 213.2 & 9.5 \\
$\mathrm{~V}_{2}$ & 10 & 220.8 & 23.9 & 283.2 & 14.8 \\
$\mathrm{~V}_{3}$ & 12 & 213.1 & 17.6 & 263.2 & 12.5 \\
$\mathrm{~V}_{4}$ & 11 & 215.5 & 18.7 & 250.3 & 12.9 \\
$\mathrm{~V}_{5}$ & 10 & 205.2 & 15.1 & 160.4 & 9.3 \\
$\mathrm{~V}_{6}$ & 10 & 208.8 & 15.3 & 162.3 & 9.4 \\
$\mathrm{~V}_{7}$ & 11 & 219.4 & 21.7 & 275.6 & 13.5 \\
& Mean & 213.4 & 18.2 & 231.3 & 11.7 \\
& S.D. & 43.67 & 5.09 & 67.6 & 3.13 \\
\hline
\end{tabular}

* From all the samples analyzed

The available nitrogen (Table 3) was nonsignificantly correlated with $\mathrm{pH}(\mathrm{r}=0.300)$ but it had significant and positive correlation with organic carbon $(r=0.941)$ and clay content $(r=0.962)$. The correlation between available phosphorus and soil $\mathrm{pH}(\mathrm{r}$ $=0.351$ ) was non - significant. However, it showed significant and positive correlation with organic carbon $(\mathrm{r}=0.972)$. The correlation between available phosphorus and clay was non-significant but positive ( $\mathrm{r}$ 
$=0.722)$. The available potassium showed nonsignificant correlation $(\mathrm{r}=0.269)$ with soil $\mathrm{pH}$ but had significantly positive correlation with soil organic carbon $(r=0.911)$ and clay content $(r=0.923)$ because the presence of most of the mica (biotite and muscovite) in finer fractions $(<0.002 \mathrm{~mm}$ size $)$ as reported by Lodha and Seth (1970). A non-significant and positive correlation $(\mathrm{r}=0.175)$ was observed between available sulphur and $\mathrm{pH}$ but it had significant and positive correlation with organic carbon $(r=0.993)$ because organic matter could be a good reservoir of sulphur. The data indicate that available sulphur was significantly and positively correlated $(r=0.910)$ with clay. Similar finding was also reported by Kaur and Jalali (2008).

Table 3. Correlation coefficient (r) values of $\mathrm{pH}$, O.C. and Clay content with available nutrients

\begin{tabular}{ccccc}
\hline & \multicolumn{4}{c}{ Available nutrients } \\
\cline { 2 - 5 } Soil properties & $\mathrm{N}$ & $\mathrm{P}$ & $\mathrm{K}$ & $\mathrm{S}$ \\
\hline $\mathrm{pH}$ & 0.300 & 0.351 & 0.269 & 0.175 \\
Organic Carbon & $0.941^{* *}$ & $0.972^{* *}$ & $0.911^{* *}$ & $0.993^{* *}$ \\
Clay & $0.962^{* *}$ & 0.722 & $0.923^{* *}$ & $0.910^{* *}$ \\
\hline
\end{tabular}

** Significant at $1 \%$

The Soil Nutrient Index Value for different villages of Harahua block of district Varanasi is depicted in fig. 1. As per Soil Nutrient Index, the soils of the area were found in the category of medium fertility status for phosphorus, potassium and sulphur and low for nitrogen. The nutrient index for nitrogen, phosphorus, potassium and sulphur were 1.13, 2.09, 2.33 and 1.70, respectively, against the nutrient index values, $<1.67$ for low, 1.67 to 2.33 for medium and $>2.33$ for high fertility status. It can be concluded that soils of Harahua block of district Varanasi are good in physical properties, neutral to slightly alkaline in reaction, low in nitrogen, medium in organic carbon, phosphorus, potassium and sulphur. It is necessary to follow balanced fertilization and nutrient management for maintaining the soil health for sustainable agriculture productivity.

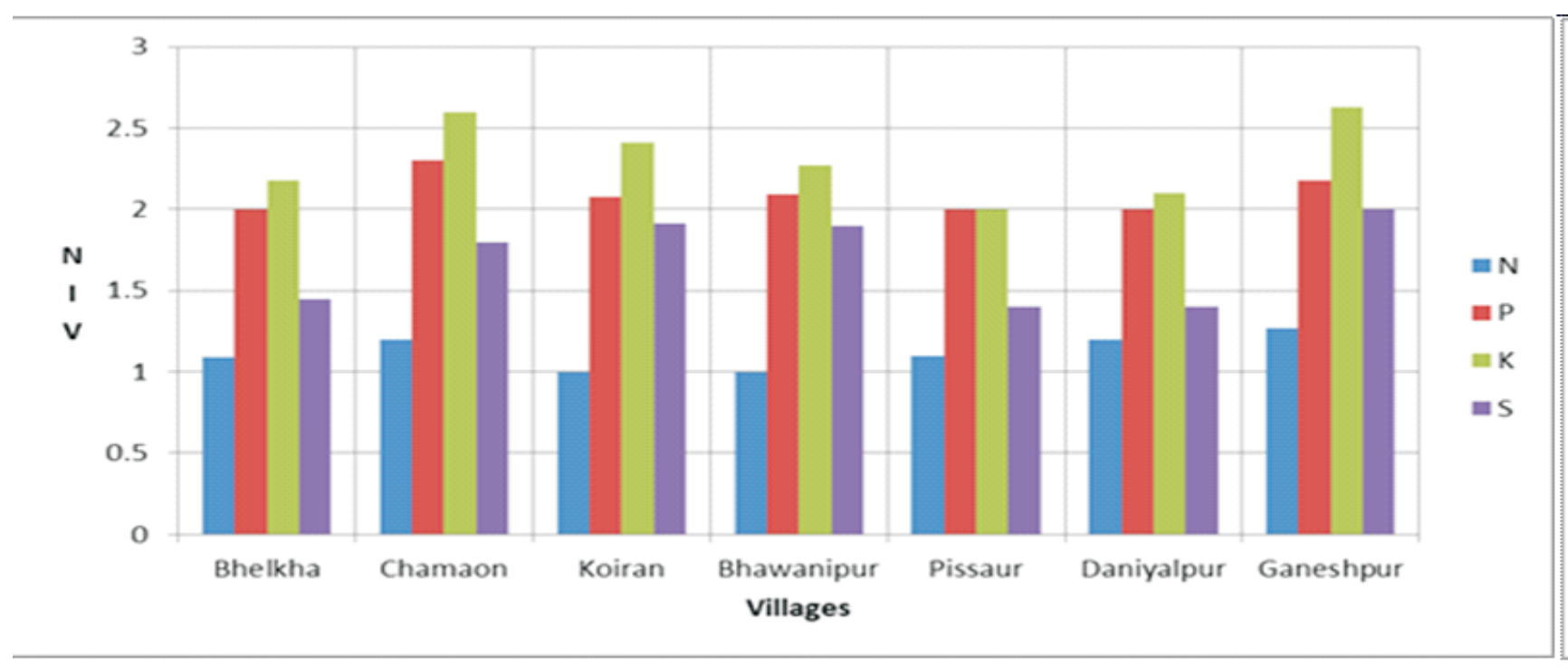

Fig. 1. Nutrient Index Value for different villages of Harahua block of district Varanasi 


\section{References}

Chopra, C.L. and Kanwar, J.S. (1999). Analytical Agricultural Chemistry. (Kalyani Publication, New Delhi).

Doneriya, B.S., Meena, R., Meena, V.S., Meena, R.S. and Dadhich, R. (2013). Soil fertility status of vegetable and pulses growing area under Marihan block in Vindhyan region of Mirzapur district. An Asian Journal of Soil Science 8, 286289.

Ghosh, A.B. and Hasan, R. (1976). Available potassium status of Indian soils. In 'Potassium in soils, crops and fertilizers'. Bulletin of the Indian Society of Soil Science 10, 1-5.

Ghosh, A.B. and Hasan, R. (1979). Phosphorus fertility status of soils of India. In 'Phosphorus in soils crops and fertilizers. Bulletin of the Indian Society of Soil Science 12, 1-8.

Ghosh, A.B. and Hasan, R. (1980). Nitrogen fertility status of soils of India. Fertiliser News 25, 1924.

Jackson, M.L. (1973). Soil Chemical Analysis. (Prentice-Hall of India Pvt. Ltd., New Delhi).

Jagdish Prasad (2004). Environmental implications of soil degradation in India - A Review. Agricultural Reviews 25, 57-63.

Kaur, S. and Jalali, V.K. (2008). Forms of sulphur and their relationship in soils of different agroclimatic zones of Jammu region. Journal of the Indian Society of Soil Science 56, 309-312.
Lodha, B.K. and Seth, S.P. (1970). The relationship between different forms of potassium and particle size in different soil groups of Rajasthan. Journal of the Indian Society of Soil Science 18, 121-127.

Muhr, G.R., Datta, N.P., Sankarasubramoney, H., Laley, V.K. and Donahue, R.L. (1965). Critical soil test values for available $\mathrm{N}, \mathrm{P}$ and $\mathrm{K}$ in different soils. In 'Soil testing in India'. (Second Edition) pp. 5256. (USAID Mission to India, New Delhi).

Olsen, S.R., Cole, C.V., Watanabe, F.S. and Deam, L.A. (1954). Estimation of available phosphorus in soil by extraction with sodium bicarbonate. (USDA Circular, Washington, DC).

Ram, H. and Dwivedi, K.N. (1994). Delineation of sulphur deficient soil groups in the central alluvial tract of Uttar Pradesh. Journal of the Indian Society of Soil Science 42, 284-286.

Subbiah, B.V. and Asijja, G.L. (1956). A rapid procedure for the estimation of available nitrogen in soil. Current Science 25, 259-260.

Walkley, A. and Black, I.A. (1934). An examination of the Degtjareff method for determination soil organic matter and a proposed modification of the chromic acid titration method. Soil Science 37, 29-38.

Received: August, 2018

Accepted: March, 2019 